\title{
Implementasi Prosedur, Peraturan dan Konsekuensi Kelas Untuk Meningkatkan Kedisiplinan Siswa Kelas 8
}

\author{
Hans Vindra Christian Sanjaya, Meicky Shoreamanis Panggabean \\ hans.sanjaya@sdh.or.id, meicky.shoreamanis@uph.edu \\ Universitas Pelita Harapan \\ The Implementation Of Classroom Procedures, Rules And Consequences To Improve Students' \\ Discipline Of Grade VIII
}

\begin{abstract}
Discipline is important in learning process as it could affect the success of learning process. Therefore, students should be responsible for their own behavior and keep the class conducive. Unfortunately, based on the researcher's observation in grade VIII at a private school, the students had disciplinary problems. They came late to class, made noises when the teacher was explaining, and slept during class. Based on theories and journals, the researcher decided to implement classroom procedures, rules, and consequences. The purposes of this research were to know whether and how the implementation of the method can improve students' discipline. The research method used was Pelton's Model of Classroom Action Research (CAR). The subjects of research were 30 students from class VIII B. The research was conducted from August $14^{\text {th }}$ to October $23^{\text {rd }}$, 2018. The instruments used were observation checklist forms, mentor's feedback and researcher journal reflection that were analyzed by using simple statistics. Data analysis results showed that the average of indicator percentage of students' discipline improved 13\% from 70\% in Issue Identification to $83 \%$ Plan activation based on mentor's observation after the implementation of the method. As conclusion, the implementation of classroom procedures, rules, and consequences could improve grade VIII students' discipline by implementing all indicators of the method, which are: created a few rules, told the reason for each rule, created reasonable and logical consequences, explained procedures, rules, and consequences clearly, rehearsed procedures, reinforced correct procedures, and be consistent in implementing procedures, rules, and consequences.
\end{abstract}

Keywords: CAR, Consequences, Discipline, Procedures, Rules

Received date: 12 Juni 2020

Article Info

Revised date: 13 Januari 2021
Accepted date: 19 Januari 2021

\section{INTRODUCTION}

In this modern era, education is crucial to build a well-manner generation. Each party in the education field must understand their important roles in educating and disciplining the future generation. The government, teachers, parents, and students must work together to achieve it. In order to learn effectively, students need to learn in a productive learning environment, which is "a classroom that is orderly and focused on learning" (Eggen \& Kauchak, 2010, p. 352). Students must be trained to be responsible with their own behavior, be discipline, and contribute well in creating conducive learning atmosphere. Unfortunately, based on the researcher's observation in grade VIII at a private school in Bangka, the students had disciplinary issue as the major issue in the classroom. Levin and Nolan (2014) point out that a discipline problem occurs when a behavior disrupts the teaching and learning activity and disturbs the rights of others to learn. The eight graders were noisy while the teacher was explaining, did not pay attention, some of them slept during class and did not bring their textbooks and stationaries. As the result, the researcher had to do some behavioral interventions to reduce students' misbehavior and improve their discipline. Eggen and Kauchak (2010, p. 358) state that "the cornerstone of an effective classroom management is a clearly understood and consistently monitored set of rules and procedures." They also claim that the foundation of a behavioral management system is specifying clear rules and consistently applying consequences. Teacher can apply a behavioral management system to 
immediately initiate desired behaviors and reduce misbehavior (Eggen \& Kauchak, 2010, p. 377; Grubaugh \& Houston,1990).

Levin and Nolan (2014) state that procedures give students necessary expectations to finish particular task optimally without asking the teachers' instructions. With clear procedures, students' confusion will be decreased. Besides that, the procedures to keep the class quiet could reduce classroom disruptions and disciplinary problem so that it can increase on-task time (Wong \& Wong, 2009, p. 170). Besides that, classroom rules have purpose to determine clear boundaries of students' behavior (Wong \& Wong, 2009, p. 149; Gable, Hester, Rock, \& Hughes 2009, p. 196) so that any confusion of behavioral expectations will decrease (Arthur, Gordon, \& Butterfield, 2006). Then, consequences are needed to reinforce the use of classroom rules (Khalsa, 2007, p. 39; Thompson \& Webber, 2010). Consequences can "reduce misbehavior and lead to the development of resilience in students" (Vitto, 2003, p. 147).

The Researcher decided to implement classroom procedures, rules, and consequences. The classroom learning environment is expected to be more conducive after implementing them. Actually, there were minor issues found during the learning process. Firstly, three out of thirty students learned slowly due to their limitation of vocabularies. However, it was just a minor problem as they eventually could catch up with the lesson by asking their teacher or their other friends for help. Secondly, five out of thirty students had low confidence in speaking English as it could be seen from their scores. It was also a minor problem as it did hinder the learning process. Eventually, based on the researcher's discussion with mentor teacher, disciplinary was the major issue and it was the issue that need to be handled by the researcher. Therefore, the researcher decided to do the research entitled "The Implementation of Classroom Procedures, Rules, and Consequences to Improve Grade VIII Students' Discipline at a private school in Bangka".

Not all the rules, procedures and consequences in this research could be applied in all schools in any regions and grades. There were other factors, such as students' characteristics, students age and cultural difference that make any rules procedures and consequences different in every region. Therefore, the implementation of classroom procedures, rules and consequences need to be adjusted based on students' characteristics, students' age and local culture. Based on the backgrounds, the purposes of study for this research are: (1) to know if the implementation of classroom procedures, rules, and consequences can influence grade VIII students' discipline at a private school in Bangka and( 2) how classroom procedures, rules, and consequences can or can not influence grade VIII students' discipline at a private school in Bangka.

\section{LITERATURE REVIEW}

\section{Discipline}

According to Saputro and Pardiman (2012), discipline in learning means student's self-control and awareness toward any form of rules, duties and responsibilities by not doing something that can disrupt the learning process. Discipline is also "a process to enable students to be aware of where their behavior infringes or affects others' rights; engage self-control and give an appropriate sense of 'choice' over their own behavior" (Rogers, 2011, p.6). From the theories above, the researcher defined students' discipline as the development of students' self-control and awareness toward their own behavior and responsibility to contribute positively in the learning community. Teachers are responsible to create conducive and pleasant learning environment where the rights of all members are protected so that the classroom can run well (Rogers, 2011). When a classroom is not managed well, disciplinary problems may be occurred. Levin and Nolan (2014, p. 11) point out that a discipline problem occurs when a behavior disrupts the teaching and learning activity and disturbs the rights of others to learn.

Levin and Nolan (2014, p. 36) also say that misbehavior problem will reduce students' learning time that may result to less learning and less achievement. In addition, "classroom discipline problems also have a negative impact on teacher effectiveness and career longevity" (Levin \& Nolan, 2014, p. 36). If the teachers frequently have to deal with disciplinary issue, their motivation to teach can be decreased and replaced by ignorant attitude (Levin \& Nolan, 2014, p. 38). Thus, disciplinary issue is important to be considered.

\section{Classroom Procedures, Rules, and Consequences}

An important thing to remember, the essence of Christian education in the context of mental and ethical development is to educate students to think and act reflectively for themselves, rather than 
to merely respond to the teacher's words (Knight, 2009). Therefore, the teacher has to explain clearly to the students the rationale and the importance of classroom procedures, rules, and consequences before applying it in the classroom. Students' dignity has to be maintained while managing the students' behavior (Curwin, Mendler, \& Mendler, 2008, p. 29).

When the teacher implements the consequences, teacher has to deliver it with compassion and empathy in order to create mutual trust between the teacher and students (Khalsa, 2007, p. 35). Curwin, Mendler, and Mendler (2008, p. 84) also claim that "consequences are best delivered calmly, privately, and with the utmost dignity" so that the effect will be positive. Must be realized, if the consequences are delivered with a negative emotion, the students usually tend to reject the teacher's words or advice (Khalsa, 2007, p. 35). Therefore, when the teacher is not capable to maintain student's dignity while implementing the rules, procedures and consequences, mistrust between teacher and students would occur and it becomes the weakness of this method. However, when the teacher could maintain students' dignity while implementing the rules, procedures and consequences, mutual trust would be built and it becomes the strength of this method. When there is a mutual trust between teacher and students, students would listen more attentively to the teacher which eventually leads to a conducive learning environment. Procedures

Khalsa (2007, p. 39) states that procedures are "how things need to be done in the classroom setting." Wong and Wong $(2009$, p. 168) also point out that a procedure is "simply a method or process for getting things done in the classroom." Levin and Nolan (2014, p. 155) define procedures as "routines that call for specified behaviors at particular times or during particular activities." Eggen and Kauchak (2010) claim procedures as the "guidelines for accomplishing recurring tasks". From all the theories, the researcher defined procedures as the guidelines of how specific things or tasks to be accomplished in the classroom. The examples of procedures are how to enter and leave the room, how to pass out and turn in materials, and how to take attendance (Levin \& Nolan, 2014 p. 155). Another examples of procedures which stated by Wong and Wong (2009) are how to start the lesson, how to end the lesson, how to keep the class quiet, and how to seek for teacher's help or attention.

\section{The Importance of Classroom Procedures}

When the teacher faces disciplinary problem, the real problem usually is not disciplined, but the lack of procedures in the classroom (Wong \& Wong, 2009, p. 165). Procedures are needed to be created so that students will be able to improve on-task behavior and finish particular task optimally without asking teachers' instructions for classroom daily event (Levin \& Nolan, 2014). Procedures are also necessary for some reasons, which are to give students necessary expectations on how things operate in a classroom so that students can be successful in the classroom activities and learning process, to reduce wasted time and confusion so that many different activities can be take place efficiently, and to reduce classroom disruptions and disciplinary problem so that it can increase on-task time (Wong \& Wong, 2009, p. 170).

\section{Rules}

Levin and Nolan $(2014$, p. 157) asserts that rules are guidelines for suitable behavior expected in the teaching and learning proces. Rules are "expectations of student behavior and clearly set limits for the student" (Khalsa, 2007, p. 39). Wong and Wong (2009, p. 149) also claim rules as what teacher expects students to follow. Based on the theories, the term rules will be defined as the guidelines of students' expected behavior which set clear limits.

Significant point to remember, rules come from God. God has written it in each humans' mind and heart (Hebrew 8:10) and commands humans to follow His rules. The teacher should expect students to follow the rules because they love God and want to please Him. The teacher also needs to model the life as an obedient disciple of Christ to the students in implementing the rules.

\section{The Need of Rules}

Orderliness is necessary in communal life so that people can live together harmoniously. In the classroom, rules are needed because classroom is dynamic and has many changing conditions (Levin $\&$ Nolan, 2014). Besides that, Wong and Wong (2009, p. 149) say that rule is one of "the basic structure for a discipline plan" which purpose is to determine limits for students to behave better. If there are clear boundaries, any confusion of behavioral expectations will decrease (Arthur, Gordon, \& Butterfield, 2006).

Rules are needed to "immediately create a work-oriented atmosphere in which students know what you expect from them" (Wong and Wong, 2009, p. 149). Rules should be designed to ensure the 
teaching and learning process to run well and manage a classroom condition which can improve students' on task behavior and learning outcomes (Levin \& Nolan, 2014, p. 158). Rules also needed to protect the right of teacher and students to have safe teaching and learning environment (Good \& Brophy, 2008 as cited in Eggen \& Kauchak, 2010, p. 355). Thus, the teachers are responsible to develop effective rules in order to maintain an effective learning environment for students to learn.

\section{Consequences}

Consequences are the results of choices (Curwin, Mendler, \& Mendler, 2008). In the context of education, rules must have consequences. Consequences are what students face if they break a rule (Wong \& Wong, 2009, p. 149). Consequences will reinforce the use of class rules (Khalsa, 2007, p. 39). Based on the theories, consequences can be defined as the result of students' choice if they break the class rules. Wong and Wong (2009, p. 153) state that there are two kinds of consequences, which are positive consequences or rewards and negative consequences or penalties. Wong and Wong (2009, p. 153) point out that rewards are the "result when people abide by the rules", while penalties are the "result when people break the rules".

\section{The Importance of Consequences}

Vitto (2003) implies that consequences are needed to deal with misbehaviors in the classroom. Teachers must implement consequences if their careful planning and effective instruction do not work to prevent students' misbehavior (Eggen \& Kauchak, 2010). Consequences should "reduce misbehavior and lead to the development of resilience in students" (Vitto, 2003, p. 147). Consequences can help students to reflect and accept the responsibility to fix the mistake so that they can choose to do better thing (Curwin, Mendler, \& Mendler, 2008, p. 83). Thus, consequences are important to be enforced in the classroom.

\section{The Implementation of Classroom Procedures, Rules, Consequences}

Below are the steps to implement classroom procedures, rules, and consequences.

1. Create a few rules (less than six).

"The rules at each level vary in specificity, but none of the teachers created more than six" (Eggen \& Kauchak, 2010, p. 363). Wong and Wong (2009, p. 150) point out that teacher has to limit the rule to a number that easy to remember, which is no more than five. Levin and Nolan (2014) also suggest to develop a Small number of rules, which is four or five. Similarly, Arthur, Gordon, and Butterfield (2006) also claim to create a few number of rules, which is six or less. So, considering what the experts said, the researcher decided to create a few rules, which is less than six so that the students can easily remember the rules.

2. Tell students the reason for each rule.

According to Eggen and Kauchak (2010), a teacher has to teach students responsibility and emphasize the reason of rules applied in the classroom. Levin and Nolan (2014) point out that any rule developed must be reasonable and make sense to students. If the rules make sense, the students will obey it not merely because they are afraid of consequences (Eggen and Kauchak, 2010). Arthur, Gordon, and Butterfield (2006) also emphasize that rationales should be provided for each rule. Therefore, the researcher would communicate the reason behind each rules to the students.

3. Create consequences that are reasonable and logical.

Consequences will bring significant effect if they are seen to be reasonable for students (Peace Corps Volunteers, 2010, p. 76). Khalsa (2007, p. 34) also argues that consequences must be logical or fit to behavior. It is because students "usually will respond better to a penalty when they see the logical connection between what they did wrong and what happens to them because of that behavior (Khalsa, 2007 , p. 34. Therefore, researcher decided to create gradual consequences so that it would be proportional to the students' rules rule. The researcher also ensured to create reasonable and logical consequences.

4. Explain classroom procedures, rules, and consequences clearly.

This step can be divided into 3 steps below.

a. Explain classroom procedures clearly.

Khalsa (2007, p. 39) points out that steps for "teaching procedures begin with explaining the procedure with a clear explanation, modelling, or demonstrating it." Levin and Nolan (2014) also say that students have to be taught the procedures through examples and demonstrations, especially when it will be used for the first time. Additionally, Wong and Wong (2009, p. 175) claim that teacher has to explain classroom procedures clearly by modelling and demonstrating it. 
b. Explain classroom rules clearly.

Wong and Wong (2009, p. 149) suggest to "clearly communicate in both verbal and written form to your students what you expect as appropriate behavior". Rules must be understood by students clearly (Arthur, Gordon, \& Butterfield, 2006). Students should understand the rules and consequences clearly "rather than having a teacher who arbitrarily changes or makes up new rules to fit the moment" (Wong and Wong, 2009, p. 149). Identically, Levin and Nolan (2014) claim that rules cannot be arbitrary. Therefore, teacher has to explain classroom rules to students clearly.

c. Consequences have been explained clearly before any violation

Jones and Jones (2016, p. 328) say that "students must be clearly aware of rules and procedures and the consequences for violating them". Jones and Jones (2016, p. 328) claim that "students must be given clear, polite cues indicating that continuation of a behavior will evoke the specified consequences". Consequences have to be clear and displayed publicly (Arthur, Gordon, \& Butterfield, 2006).

5. Rehearse classroom procedures by doing it over and over.

Jones and Jones (2016, p. 210) suggest to have students practice the procedure until they do it correctly. Similarly, Wong and Wong $(2009$, p. 176) point out that a teacher has to rehearse the procedures by asking students to practice it correctly under the teacher's guidance and asking them to repeat it until becomes routines. Additionally, Levin and Nolan (2014) say that because students usually do not immediately use the procedures, the teacher needs to have students practice it, give feedback and remind students the correct procedure every time it is used in the classroom. Levin and Nolan (2014) state that the procedures should become students' routines. A routine means "the learned behavior occurring even without teacher supervision" (Khalsa, 2007, p. 36).

6. Reinforce correct procedures by giving student praise or positive words.

Reinforcing the correct behavior is the important step to teach procedure according to Jones and Jones (2016, p. 210). Wong and Wong (2009, p. 177) also say that teacher should reinforce a correct procedure and praise the students when they have practiced it well. Wong and Wong (2009, p. 177) add that teacher also needs to reteach the incorrect procedure and give corrective feedback. So, the researcher would reinforce the correct procedures by giving students praise, smile, or positive words.

7. Be consistent in the implementation.

In a well-managed classroom, consequences are used consistently when necessary (Vitto, 2003, p. 146). Eggen and Kauchak (2010) also say similar thing that teacher has to implement the rules consistently and fair. Jones and Jones (2016, p. 328; Cothran et al., 2003, p. 441)) also emphasize the importance to be "as consistent as possible in employing consequences". Similarly, Khalsa (2007, p. 34) agrees that consequences should always be consistently enforceable. Consequences "will have their greatest impact when they are immediate, consistent, respectful" to be implemented (Peace Corps Volunteers, 2010, p. 76). The definition of consistent according to Curwin, Mendler, and Mendler (2008, p. 89) is "always caring about each of your students and caring means doing what will best help each student be successful and become more responsible." So, the researcher would do this step by: implementing classroom rules consistently and implementing the consequences consistently when violation of the rules occurred.

\section{RESEARCH METHODOLOGY}

The Researcher conducted a Classroom Action Research (CAR) to solve the problem found in the classroom. CAR is a research conducted in class by implementing an action, then understanding the effect of the action to the research subject (Trianto, 2011). The purpose of CAR is to improve the quality of learning process and the teacher's performance in class (Arikunto, Suhardjono, \& Supardi, 2012. It is a powerful mindset for teaching because it emphasizes teacher's role as a reflective practitioner who is continually observant, thoughtful, and willing to examine personal actions in order to create the best possible practices for students (Pelton, 2010). CAR model used in this research is based on Pelton model of action research. Pelton Model of Action research consists of five phases which are Issue Identification, data collection, Action Planning, Plan Activation and Outcome Assessment (Pelton, 2010). The research was done in a vocational Christian junior high school in Bangka from August 14 to September 23, 2018, in the odd term of 2018/2019 academic year with 30 students that consist of 13 
boys and 17 girls from class VIII B as the research subject. The school has biblical visions and missions and implements a modified national curriculum.

\section{DISCUSSION}

The implementation of classroom procedures rules and consequences was executed according to the procedure. It could be seen from the collected data below:

1. Observation Checklist

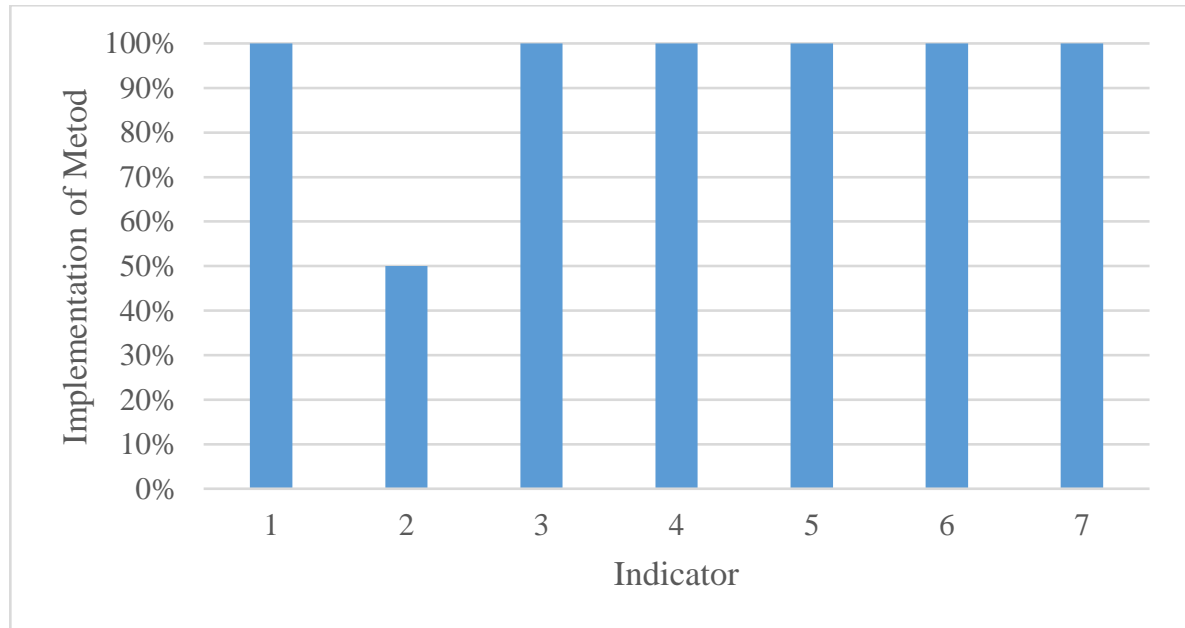

Figure 4. 1 Mentor observation checklist result on action variable

Note. Steps of the Implementation of Classroom Procedures, Rules, and Consequences:

1. Create a few rules (less than six).

2. Tell students the reason for each rule.

3. Create consequences that are reasonable and logical.

4. Explain classroom procedures, rules, and consequences clearly.

5. Rehearse classroom procedures by doing them over and over.

6. Reinforce correct procedures by giving students praise, smiles, or positive words.

7. Be consistent in implementing classroom procedures, rules, and consequences.

Figure 4.1 shows that indicators 1, 2, 3, 4, 5, and 6 of the implementation of the method have been implemented optimally $100 \%$. However, indicator 2 only reached $50 \%$ and it was still below the minimum criteria which is good or above $60 \%$. According to researcher's mentor, the researcher did not fulfill a statement in indicator 2 which is to tell students the reason for each rule. Based on mentor's comment on the observation checklist form, the researcher did not explain clearly about few reasons why they should follow each rule. However, the average of indicator percentage from mentor's observation reached $93 \%$ and it categorized as very good category. As conclusion, all indicators have been implemented optimally, except indicator 2 .

The Implementation of classroom procedures rules and consequences influence the students' discipline. In this research, students discipline was measured by researcher's mentor teacher. Mentor's observation results were analyzed by comparing students' discipline percentage per indicator in Issue Identification and in Plan activation. In other words, before and after the implementation of classroom procedures, rules, and consequences (see Figure 4.2). The average of indicator percentage of students' discipline improved 13\% from 70\% in Issue Identification to 83\% in Plan Activation. 


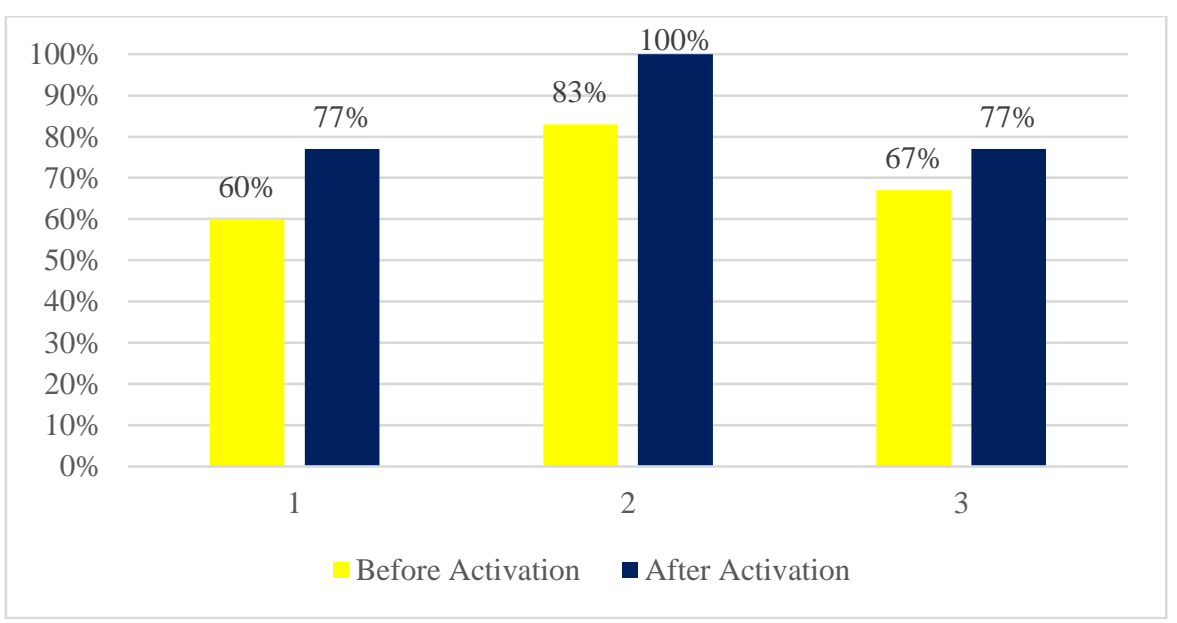

Figure 4.2 Comparison of Problem Variable based on mentor checklist result

Note. Students' Discipline Indicators:

1. Develop self-control

2. Prepare to learn

3. Show respect

\section{Figure 4.2.1 Develop Self-Control}

Figure 4.2 shows that indicator 1 improved $17 \%$ from $60 \%$ in Issue Identification to $77 \%$ in Plan activation. Another finding is that Indicator 2 improved $17 \%$ from $83 \%$ in Issue Identification to $100 \%$ in Plan activation. From the result, it is clear that the implementation of classroom procedures, rules, and consequences influence the students' discipline. The chart indicates three things:

Firstly, because students have self-control, the class becomes a more conducive place to learn. It is mentioned earlier, Saputro and Pardiman (2012) stated that discipline in learning means student's have self-control and awareness toward any form of rules, duties and responsibilities by not doing something that can disrupt the learning process This allows the conclusion that class becomes more peaceful and activities run more smoothly because greater self-control is exercised by students.

Secondly, self-control leads students to a better academic achievement. Self-control is instrumental in students' academic success in particular when they are both in middle and high-school. Steinberg, L. (2015) conveys that if we want to improve our adolescents' achievement, we have to rethink secondary education so that it's more geared to strengthening the self-control that students need to be successful in school and beyond.

Thirdly, self-control makes students become more independent. This statement found a clear support from Levin and Nolan (2014) who described that classroom procedures give students necessary expectations to finish particular task optimally without asking the teachers' instructions for classroom daily event.

These three conclusions have implied that teachers can use the results of this study to start researching for theories, trategies and best practices on helping students develop their self-control. The aspects above can also be a driving factor for teachers to learn more about the implementation of classroom procedures, rules, and consequences in online setting. A growing body of researches have suggested that in the future blended-learning will be the future of education.

\section{Figure 4.2.1 Prepare to Learn}

The result shows that Indicator 2 improved 17\% from 83\% in Issue Identification to $100 \%$ in Plan activation. Students were prepared to learn by following the class rules, which are: come on time to class, bring their English textbook to class before the class starts, and do the task assigned by the teacher. Wong and Wong $(2009$, p. 165) said that when the teacher faces disciplinary problems, the real problem usually is not disciplined, but the lack of procedures in the classroom. The increment of $17 \%$ in this second indicator confirms that the implementation of classroom procedures, rules, and consequences reduce misbehavior and lead to the development of resilience in students (Vitto, 2003, p. 147). 
It is good to highlight that a class can truly success if both teachers and students are prepared to learn. Coming on time to class and bring the textbook indicate the students preparedness. The readiness to learn further demonstrates by the students discipline in doing assignments.

Mood swings are most volatile when people are in their teenage years. The respondents are all teenagers thus they most likely to change. Teachers need to understand the importance of the psychology developmental stages and the characteristics of each phase. It needs to be combined with best approaches in instilling healthy learning habits so the students can be a lifelong learner.

Being able to learn ceaselessly is a competency that should be possessed by students in this rapid global change. It affects on the teachers teaching style as well as schools' explicit and hidden curriculum. Thus, teachers should take more responsibility for setting goals, identifying resources for learning, and reflecting on and evaluating their learning (Collins 2009:620).

Figure 4.2.3. Show Respect

Indicator 3 improved $10 \%$ from $67 \%$ in Issue Identification to $77 \%$ in Plan activation. Students' could show respect by following the class rules, which are: Do not sleep during class and do not make noise while the teacher is talking. The teacher always reminds students those five rules in the beginning of the class. The result of mentor's observation checklist show that the implementation of classroom procedures, rules, and consequences can improve students' discipline. It can be seen from the improvement of students' discipline percentage as a whole and the improvement of each indicators of students' discipline from Issue Identification to Plan Activation, which is above $60 \%$ or good category.

The findings related to third indicator at least hints that the implementation of classroom procedures, rules, and consequences also develops students' social skills. Showing respect is an integral part of communication skills and this skill plays a significant role in all walks of life. As a consequence, classroom procedures should be rehearsed until become students' routines (Levin \& Nolan, 2014).

Teachers are required to be observant, open-minded, and open for discussion. There are increasing generational gaps between students and teachers. The characteristics of each generation is different, so is the communication ways. The students' respect towards teachers seem decreasing and maybe the concept of respect need to be discussed. Thus, to have this positive effect continue into the future, being consistent as is advised by Levin and Nolan is mandatory. Yet, it needs to be accompanied by teachers and students willingness to communicate, exchange ideas and listen to each other respectfully.

\section{CONCLUSION}

By referring to the analysis and discussion, the researcher concluded that the implementation of classroom procedures, rules, and consequences can improve Grade VIII students' discipline. The average of students' discipline indicator percentage improved from 13\% in Issue Identification (70\%) to Plan activation ( $83 \%$ ) based on researcher mentor's observation checklist. Thus, The implementation creates a conducive learning atmosphere and minimizes students' misbehavior.

The improvement occurs after all of the procedures were consistently implemented: The researcher created only a few rules (less than six), informed the students the reason for each rule, created consequences that were reasonable and logical, and explained classroom procedures, rules, and consequences clearly. After that the researcher rehearsed classroom procedures, reinforced correct procedures by giving students praises, smiles, or positive words.

\section{BIBLIOGRAPHY}

Arikunto, S., Suhardjono, \& Supardi. (2012). Penelitian tindakan kelas. Jakarta: PT Bumi Aksara. environments. South Melbourne: Thomson.

Collins, J. (2009). Lifelong Learning in the 21st Century and Beyond. RadioGraphics, 29(2), 613-622.

Curwin, R. L., Mendler, A. N., \& Mendler, B. D. (2008). Discipline with dignity : new challenges, new solutions (3 ed.). Alexandria, Virginia USA: Association for Supervision and Curriculum Development. 
Cothran, D. J., Kulinna, P. H., \& Garrahy, D. A. (2003). "This is kind of giving a secret away...”: students' perspectives on effective class management. Teaching and Teacher Education, 19(4), 435-444. https://doi.org/10.1016/s0742-051x(03)00027-1

Eggen, P., \& Kauchak, D. (2010). Educational psychology: Windows on classrooms. Boston: Pearson.

Fraenkel, J. R. and Wallen, N. E. (2008). How to design and evaluate research in education. New York: McGraw-Hill.

Gable, R. A., Hester, P. H., Rock, M. L., \& Hughes, K. G. (2009). Back to Basics: Rules, Praise, Ignoring, and Reprimands Revisited. Intervention in School and Clinic, 44(4), 195-205. https://doi.org/10.1177/1053451208328831

Steve Grubaugh \& Richard Houston (1990) Establishing a Classroom Environment That Promotes Interaction and Improved Student Behavior. The Clearing House. A Journal of Educational Strategies, Issues and Ideas, 63(8), 375-378, DOI: 10.1080/00098655.1990.10114133

Khalsa, S. S. (2007). Teaching discipline and self-respect: Effective strategies, anecdotes, and lessons for successful classroom management. California: Corwin Press.

Knight, G. (2009). Filsafat \& pendidikan: Sebuah pendahuluan dari perspektif kristen [Philosophy \& education: An introduction in Christian perspective]. (C. E. Citraningtyas, Trans.) Jakarta: Universitas Pelita Harapan.

Levin, J., \& Nolan, J. (2014). Principles of classroom management: A professional decision-making model (7 ed.). USA: Pearson Education. 93

Peace Corps Volunteers. (2010). Classroom management idea book. Washington: Peace Corps.

Pelton, R. P. (2010). Action research for teacher candidates: Using classroom data to enhance instruction. Lanham, MD: Rowman \& Littlefield Education.

Rogers, B. (2011). You know the fair rule: Strategies for positive and effective behaviour (3 ed.). Victoria, Australia: ACER Press.

Saputro, S. T., \& Pardiman. (2012). Pengaruh disiplin belajar dan lingkungan teman sebaya terhadap prestasi belajar mahasiswa program studi pendidikan akuntansi angkatan 2009 fakultas ekonomi universitas negeri yogyakarta. Jurnal Pendidikan Akuntansi Indonesia. 10 (1), 78-97.

Steinberg, L. (2015). How Self-Control Drives Student Achievement. Educational Leadership, 73(2), $28-32$.

Thompson, A. M., \& Webber, K. C. (2010). Realigning Student and Teacher Perceptions of School Rules. A Behavior Management Strategy for Students with Challenging Behaviors. Children \& Schools, 32(2), 71-79. doi:10.1093/cs/32.2.71

Trianto. (2011). Panduan lengkap penelitian tindakan kelas [classroom action research] teori dan praktik. Jakarta: Prestasi Pustakaraya.

Trussell, R. P. (2008). Classroom Universals to Prevent Problem Behaviors. Intervention in School and Clinic, 43(3), 179-185. https://doi.org/10.1177/1053451207311678

Vitto, J. (2003). Relationship-driven classroom management: strategies that promote student motivation. California, USA: Corwin Press.

Wong, H. K., \& Wong, R. T. (2009). The first day of : How to be an effective teacher. Mountain View, CA: Harry K. Wong Publications, Inc. 